Article

\title{
Establishment of A Reversibly Inducible Porcine Granulosa Cell Line
}

\author{
Yinshan Bai ${ }^{1,2} \oplus$, Cui Zhu ${ }^{1}$, Meiying Feng ${ }^{3}$, Bo Pan ${ }^{2} \oplus$, Shouquan Zhang ${ }^{3}$, Xiaoshu Zhan ${ }^{2}$, \\ Huifang Chen ${ }^{1}$, Bingyun Wang ${ }^{1}$ and Julang $\mathrm{Li}^{2, *}$ \\ 1 School of Life Science and Engineering, Foshan University, Foshan 528231, China; \\ xuefei200403@163.com (Y.B.); juncy2010@gmail.com (C.Z.); chenhuifang07@163.com (H.C.); \\ bywang63@163.com (B.W.) \\ 2 Department of Animal Biosciences, University of Guelph, Guelph, ON N1G 2W1, Canada; \\ bopan@uoguelph.ca (B.P.); xzhan01@uoguelph.ca (X.Z.) \\ 3 College of Animal Science, South China Agricultural University, Guangzhou 510642, China; \\ jony.ya@163.com (M.F.); sqzhang@scau.edu.cn (S.Z.) \\ * Correspondence: jli@uoguelph.ca; Tel.: +519-824-4120 (ext. 52713)
}

Received: 24 November 2019; Accepted: 6 January 2020; Published: 8 January 2020

check for updates

\begin{abstract}
Granulosa cells (GCs) are the key components of ovarian follicles for regulating oocyte maturation. Previous established GC lines have allowed prolonged proliferation, but lost some physiological features owing to long-term immortalization. This study was to establish an induced immortal porcine GC line with reversible proliferation status by the tetracycline inducible (Tet-on) 3G system. Our conditional immortal porcine GCs (CIPGCs) line steadily propagated for at least six months and displayed primary GC morphology when cultured in the presence of $50 \mathrm{ng} / \mathrm{mL}$ doxycycline [Dox (+)]. Upon Dox withdrawal [Dox (-)], Large T-antigen expression, reflected by mCherry fluorescence, gradually became undetectable within $48 \mathrm{~h}$, accompanied by less proliferation and size increase. The levels of estradiol and progesterone, and the expression of genes associated

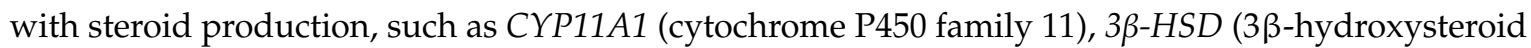
dehydrogenase), StAR (steroidogenic acute regulatory protein), and CYP19A1 (cytochrome P450 family 19 subfamily a member 1 ), were all significantly higher in the Dox (-) group than Dox (+) group. The CIPGCs could switch into a proliferative state upon Dox induction. Interestingly, the expression of StAR and CYP19A1 in the CIPGCs (-Dox) was significantly increased by adding porcine follicular fluid (PFF) to mimic an ovary follicle environment. Moreover, PFF priming the CIPGCs in Dox (-) group resulted in similar estradiol production as that of primary GC, and enabled this cell line to respond to gonadotrophins in estradiol production. Collectively, we have established an inducible immortal porcine GC line, which offers a unique and valuable model for future research on the regulation of ovarian functions.
\end{abstract}

Keywords: granulosa cells; Tet-on 3G; Large T; proliferation; immortalization; steroidogenesis

\section{Introduction}

Granulosa cells (GCs) play important roles in oocyte development, ovulation, and pregnancy [1]. Granulosa cell culture in vitro is a valuable model for studying female reproductive hormone synthesis, follicular development, and fertility [2]. However, culture of primary GCs has been difficult owing to their limited numbers and life span in vitro, as well as their quick luteinization within a short period of time after isolation [3], which have restrained their research potential in vitro.

Previous studies have reported that GCs can be immortalized by transfecting genes such as Simian virus 40 Large T-antigen (Large T) [4,5] or telomerase reverse transcriptase (Tert) [6]. This ability is 
because of their inhibition on cell cycle suppressors (p53 and pRb), cell proliferation enhancing (Large $\mathrm{T}$ ), or telomer extension (Tert) (reviewed in the work of [7]). The immortalized GC lines from various species have been previously established by expression of Large $\mathrm{T}$ and Tert $[4,5,8]$ or spontaneous immortalization [9]. These GC lines can proliferate in vitro and retain some functional characteristics of primary GCs [10]. However, many of the key physiological functions are lost in GC lines owing to permanent cellular transforming [4,9-11]. For example, several porcine GC lines, including AVG-16 [12], MDG2.1 [13], PGC-2 [14], and JC-410 [15], were unable to express follicular stimulating hormone receptor (FSHR), luteinizing hormone receptor (LHR) [10], or cytochrome P450 family 19 subfamily a member 1 (CYP19A1) [15], which are key genes for granulosa function. Additionally, other GC line such as JC-410 could only produce a very low level of progesterone [10], while PGV lost the ability to produce progesterone [10]. Thus, a GC line that more closely resembles the primary GCs would be desirable for studying the function and regulation of folliculogenesis [16].

To address the issue regarding the loss of physiological function of transfected cells established via constitutive expression of Large $\mathrm{T}$ or Tert after long-term culture [16,17], a reversible cell line approach has recently received a great deal of interest for the establishment of multiple cell lines from other somatic tissues [18-21]. More functional phenotypes of the immortal cells might be recovered by turning off the expression of Large T or Tert using the Cre/LoxP-based inducible system [17]. Thus, a reversible immortalized GC line may be desirable for studying their function in vitro. The tetracycline (Tet)-on 3G system, otherwise, may provide an alternative effective inducible platform to regulate gene expression in many cells from human and animals [22]. Therefore, this study was carried out to establish a reversible porcine GCs line by turning on/off the expression of Large T using the Tet on-3G system, and investigated whether the established GCs line might have the biological function of primary GCs. Here, we report the generation of a reversible porcine GC line, termed as conditional immortal porcine GC (CIPGC), which is capable of estradiol production in response to gonadotrophins, offering a unique in vitro model for studying the functional regulation of these important cells during ovarian follicular development.

\section{Materials and Methods}

\subsection{Construct of the Inducible and Reversible Large T Lentiviral Plasmid}

The inducible and reversible Large $\mathrm{T}$ lentiviral plasmid was constructed by remodeling the Tet-on 3G lentiviral vector (Addgene, \#50661, Cambridge, MA, USA). Tet-on 3G lentiviral plasmid was integrated with inducible expression of Large $\mathrm{T}$ and mCherry gene, and manipulated by tetracycline (Tet)-controlled transcriptional activation. In addition, the puromycin resistance gene (Puro) was used for cell screening. The tetracycline inducible (Tet-on) lentiviral expression vectors with TRE 3G promoter bound to rrTA and doxycycline (Dox, a more stable tetracycline analogue, Sigma, D9891, St. Louis, MO, USA) were used in this study. These vectors were applied to control the expression of the gene of Large $\mathrm{T}$ and reporter gene of mCherry, and jointed by Thosea asigna virus $2 \mathrm{~A}$ self-cleaving peptides (T2A) sequence.

\subsection{Isolation and Cultivation of Granulosa Cells}

Pig ovaries were collected from a local commercial slaughterhouse and transported to the lab in warm sterile saline $\left(38^{\circ} \mathrm{C}\right)$ within $2 \mathrm{~h}$. Primary granulosa cells (GCs) were isolated using $10 \mathrm{~mL}$ syringe from 2-3 mm ovarian follicles followed by three washes of warm sterile saline. Then, the primary GCs without cumulus-oocyte complexes (COCs) were collected and then subjected to low-speed centrifugation at $1000 \mathrm{rpm}$ for $5 \mathrm{~min}$, followed by three washes with PBS to get rid of white blood cells. The primary GCs were then transferred to $10 \mathrm{~cm}$ culture dish for in vitro culture with DMEM medium (11960044, Gibco, Grand Island, NE, USA) supplemented with 10\% fetal bovine serum (FBS, Gibco, 10099-141), 1\% GlutaMAX ${ }^{\mathrm{TM}}$ supplement (Gibco, 35050061), and $20 \mathrm{ng} / \mathrm{mL}$ epidermal growth factor (EGF, AF-100-15, Peprotech, Rocky Hill, CT, USA). On the second day of isolation, the primary 
GCs were changed culture medium, followed by three washes with PBS to remove the remaining unattached white blood cells.

\subsection{Lentivirus Packaging, Infection, and Cell Screening}

The lentiviral gene transfer plasmids of $10 \mu \mathrm{g}$ pLVX-Tet3G-Large T-T2A-mCherry-Puror, as well as the package plasmids of $10.4 \mu \mathrm{g}$ psPAX2 and $3.5 \mu \mathrm{g}$ pMD2.G, were transfected with $70 \%$ confluent $10 \mathrm{~cm}$ plates of 293FT cells (ATCC, EY-X0869, Rockefeller, MD, USA) by polyfect transfection reagent (301105, Qiagen, Hilden, Germany). The recombinant lentiviral particles found in the supernatant were collected at 48 and $72 \mathrm{~h}$, followed by filtration $(0.45 \mu \mathrm{m})$ into sterilized $50 \mathrm{~mL}$ centrifuge tubes. The high-concentration lentivirus was harvested through an ultrafiltration device (Millipore, UFC9011096, Germany) by centrifuging at $4000 \mathrm{rpm}, 4{ }^{\circ} \mathrm{C}$ for $30 \mathrm{~min}$, and lentivirus aliquots were stored at $-80{ }^{\circ} \mathrm{C}$ until further use. Viral particles were then suspended in $500 \mu \mathrm{L}$ GC complete medium with $6 \mu \mathrm{g} / \mathrm{mL}$ polybrene (Sigma, H9268), and lentiviral solution at a multiplicity of infection (MOI) of 20 was applied to infect GCs after first passage for $6 \mathrm{~h}$. Infected GCs were continued to culture for another $48 \mathrm{~h}$, followed by 14-day screening with $1 \mu \mathrm{g} / \mathrm{mL}$ puromycin (Gibco, A1113803) and induction of $50 \mathrm{ng} / \mathrm{mL}$ Dox. The infection results were analyzed by observing mCherry expression under a fluorescent microscope (IX73, Olympus, Tokyo, Japan).

The CIPGCs were cultured in DMEM supplemented with 10\% FBS, 1\% GlutaMAX ${ }^{\mathrm{TM}}$, and $50 \mathrm{ng} / \mathrm{mL}$ Dox, and maintained long-term propagation for more than six months with consecutive passages. This long-term cultured CIPGCs were treated with or without Dox for six days, and then used for the determinations of cell cycle, cell proliferation, immunofluorescence, mRNA expression, and steroid hormone production.

\subsection{Cell Cycle Analysis}

Cell cycle analysis were conducted to compare the proliferative ability of CIPGCs when treated with or without Dox. The CIPGCs with and without Dox induction for 2, 4, and $6 \mathrm{~d}$ were harvested, respectively, and fixed with $70 \%$ ice-cold ethanol at $4{ }^{\circ} \mathrm{C}$ overnight, centrifuged at $1500 \mathrm{rpm}$ for $5 \mathrm{~min}$, and then resuspended in PBS. Subsequently, the cells were stained with $50 \mu \mathrm{g} / \mathrm{mL}$ propidium iodide (CF0032, Beijing Dingguo Changsheng Biotechnology Co, Beijing, China), $100 \mu \mathrm{g} / \mathrm{mL} \mathrm{RNase}$ A (9901-99-4, Genview, Galveston, TX, USA), and 0.2\% Triton X-100 for 30 min in the dark at room temperature. Cell cycle analysis was conducted using a FACSAria II system (BD Biosciences, Franklin Lakes, NJ, USA).

\subsection{Cell Proliferation Assays}

The long-term cultured CIPGCs after treatment with or without Dox for six days were seeded into the 96-well plates at a cell density of $1 \times 10^{3}$ per well, and were examined for cell proliferation via the CellTiter 96 ${ }^{\circledR}$ AQueous One Solution Cell Proliferation Assay (MTS; G3582, Promega, Madison, WI, USA). Briefly, $20 \mu \mathrm{L}$ of CellTiter $96^{\circledR}$ AQueous reagent was added into each well of the 96-well assay plate containing sample and $100 \mu \mathrm{L}$ of culture medium. The plate was incubated at $37^{\circ} \mathrm{C}$ for $1 \mathrm{~h}$ in a humidified atmosphere with $5 \% \mathrm{CO}_{2}$, and was recorded under the absorbance at $490 \mathrm{~nm}$ using a 96-well plate reader using an ELISA machine.

\subsection{Immunofluorescence}

After six days of Dox induction, immunofluorescent staining was performed [23], and the CIPGCs were treated with 1\% bovine serum albumin (BSA, Sigma-HZB0148) and 0.01\% Triton-100 (AR-0341, Beijing Dingguo Changsheng Biotechnology Co). Then, the CIPGCs were treated with primary antibodies (Rabbit anti-FSHR, Absin-abs120271, 1:200 dilution, Univ-bio, Shanghai, China; Rabbit anti-CYP11A1, AB2060, 1:200 dilution, Liankebio, Hangzhou, China; Rabbit anti-3ß-HSD, ab150384, 1:200 dilution, Abcam, Cambridge, UK, USA) at $4{ }^{\circ} \mathrm{C}$ overnight. After washing three times with PBS for $5 \mathrm{~min}$, CIPGCs were incubated for $1 \mathrm{~h}$ with secondary antibodies (Alexa Fluor ${ }^{\circledR} 488$ Goat 
Anti-Rabbit IgG, Invitrogen, A11034 and Alexa Fluor ${ }^{\circledR} 568$ Goat Anti-Rabbit IgG, Invitrogen, A11036, all for 1:500 dilution, Camarillo, CA, USA) at room temperature. Nuclei were counterstained with $10 \mu \mathrm{g} / \mathrm{mL}$ Hochest33342 (Molecular Probes, H3570, Waltham, MA, USA) for $10 \mathrm{~min}$. Fluorescence signals were detected using the fluorescent microscope.

\subsection{RNA Extraction and Quantitative Reverse Transcriptase (RT)-PCR}

In order to compare the relative mRNA expression of specific genes in long-term cultured CIPGCs after treatment with or without Dox for six days, total RNA was extracted from CIPGCs in both groups using the RNeasy Mini Kit (Qiagen, Hilden, Germany) according to the manufacturer's instructions. The cDNA was synthesized from $1 \mu \mathrm{g}$ RNA using Superscript cDNA Reverse Transcription Kit (Invitrogen, Camarillo, CA, USA). Quantitative RT-PCR was performed using SYBR Green PCR Master Mix (Bio-Rad, Hercules, CA, USA) in an Applied CFX Connext ${ }^{\mathrm{TM}}$ Real-time PCR machine. The primer sequences of targeted genes ( $L H R$, luteinizing hormone receptor; CYP11A1, cytochrome P450 family

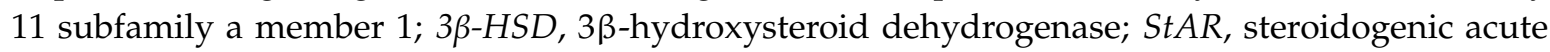
regulatory protein; CYP19A1, cytochrome P450 family 19 subfamily a member 1; LIFR, leukemia inhibitory factor receptor; PCNA, proliferating cell nuclear antigen; CCNB1, cyclin B1) are given in Supplementary Table S1. The mRNA expression of targeted genes was normalized to that of house keeping gene GAPDH.

\subsection{Morphology and Phentypic Analysis of CIPGCs with or without Dox}

In order to investigate the efficiency of CIPGCs to be reversible controlled by Dox withdrawal, we cultured the long-term propagated CIPGCs with DMEM, 10\% FBS, and 1\% GlutaMAX Dox for 14 days, when most cells became ageing and dead. On day 15, addition with 50 ng/mL Dox was re-introduced in the culture system for another nine days, when the CIPGCs reached almost confluency. Morphology changes along with mCherry expression were observed under fluorescent microscope accordingly.

\subsection{Determination of Steroid Hormones' Secretion}

The supernatants of the CIPGCs with or without Dox induction were collected at 2, 4, and $6 \mathrm{~d}$. The levels of estradiol and progesterone in the supernatant were detected by estradiol ELISA Kit (No. 582251, Cayman, Arbor, MI, USA) and progesterone ELISA Kit (No. 582601, Cayman), following the protocols of the manufacturers, respectively.

In order to further compare the steroid hormone productions of the CIPGCs with those of primary GCs, the cell supernatants were harvested after treatments with $0.01 \mathrm{U} / \mathrm{mL}$ porcine FSH (Sioux Biochemicals, Sioux Center, IA, USA) [24] or 0.02 U/mL LH (Sioux Biochemicals) [25] for $24 \mathrm{~h}$, and then the levels of estradiol were determined as mentioned above.

\subsection{Statistics Analysis}

Data analysis was performed using Student's $t$-test in the GraphPad software (GraphPad Software, La Jolla, CA, USA) to evaluate the statistical differences of groups. Student's $t$-test was used for the comparison of results between two groups [Dox (+) vs. Dox (-)]. One-way analysis of variance (ANOVA) with Duncan's multiple comparison was employed for the comparison of data among three groups. The results were presented as the means \pm standard error $(n \geq 3)$. $p<0.05$ was indicated as a statistically significant difference. All the experiments were repeated at least three times, except that the immunofluorescent analysis was repeated twice. 


\section{Results}

\subsection{Construction of the Inducible Large T Expressing Lentiviral Plasmid}

A lentivirus-based inducible Large $\mathrm{T}$ and mCherry expression vector was constructed. The inducible expression was achieved using the Tet-on 3G system, which linked Large $\mathrm{T}$ and mCherry coding sequence via T2A sequence, allowing simultaneous expression of both of the Large T and red florescence proteins (Figure 1). Puromycin was used as a selection antibiotic marker to achieve stable vector integration.
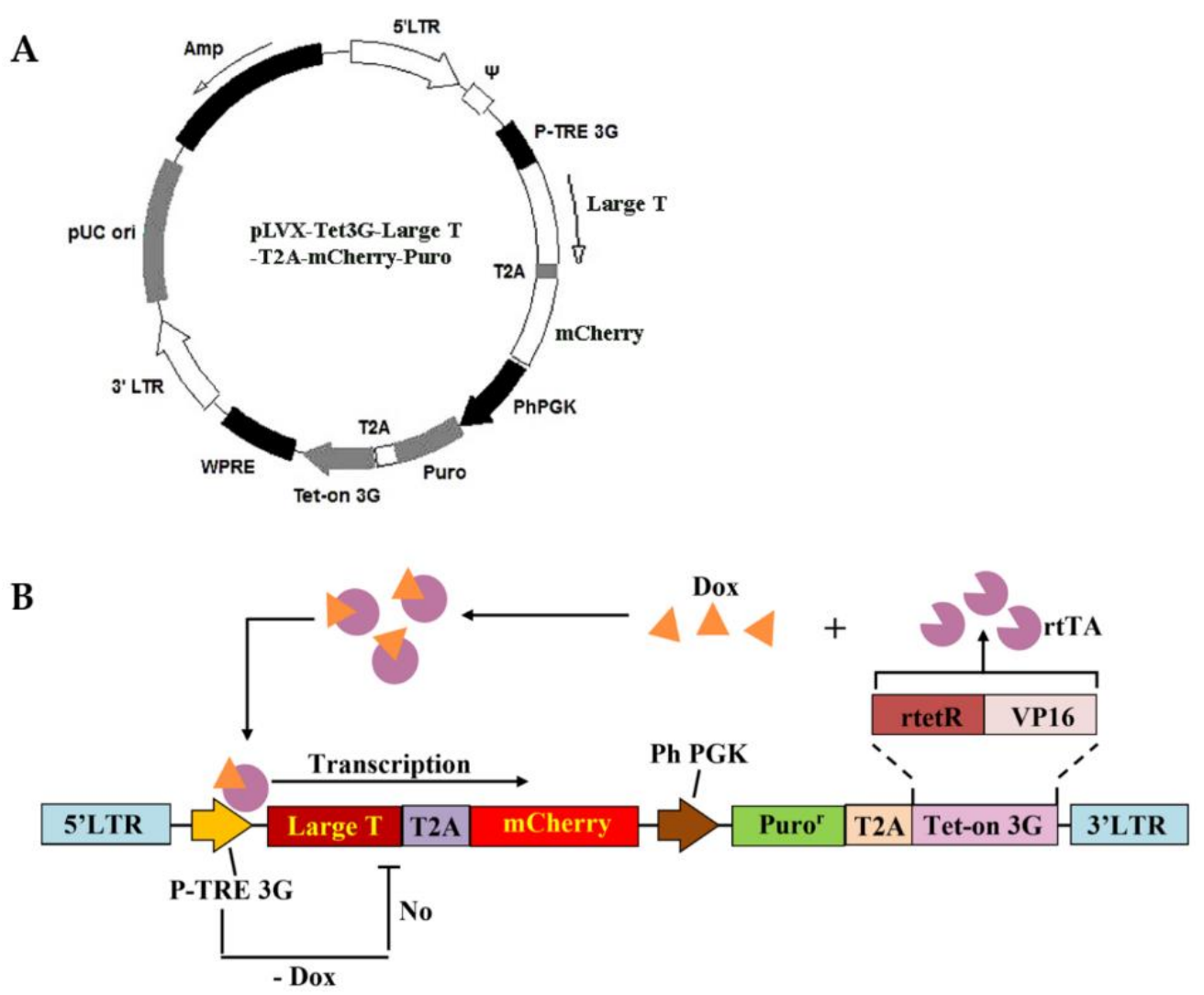

Figure 1. Lentiviral plasmid design and construction. (A) The lentiviral plasmid map; (B) the elements the of constructed plasmid: LTR, long terminal repeats sequence; P-TRE 3G, third generation Tet-inducible promoter; Large T, Simian vacuolating virus 40 Large T antigen; T2A, 2A self-cleaving peptides; mCherry, a red fluorescent protein; Ph PGK, human phosphoglycerate kinase 1 promoter; Puro $^{r}$, puromycin resistance gene; Tet-on 3G (rtTA), third-generation doxycycline-responsive transactivator protein.

\subsection{Isolation and Lentivirus Transduction of Porcine GCs}

Porcine primary GCs isolated from ovarian follicles showed a small and fibroblast-like morphology under primary culture (Figure 2A). After five days, these GCs stopped proliferating and appeared to be larger and longer; a morphology that is consistent with differentiative GCs (Figure 2B). Porcine primary GCs were transduced with lentivirus harboring the Tet-on-Large T-T2A-mCherry gene. Upon induction of Large T expression with Dox, this transduced GC line, named conditional immortal porcine GC (CIPGCs), displayed proliferation morphology of small and non-stretched cells, and expressed mCherry fluorescence. In the presence of puromycin selection, the induced stable Large T expressed GCs steadily proliferated and passaged in vitro for at least six months (Figure 2C,D; Supplementary Figure S1). 
A
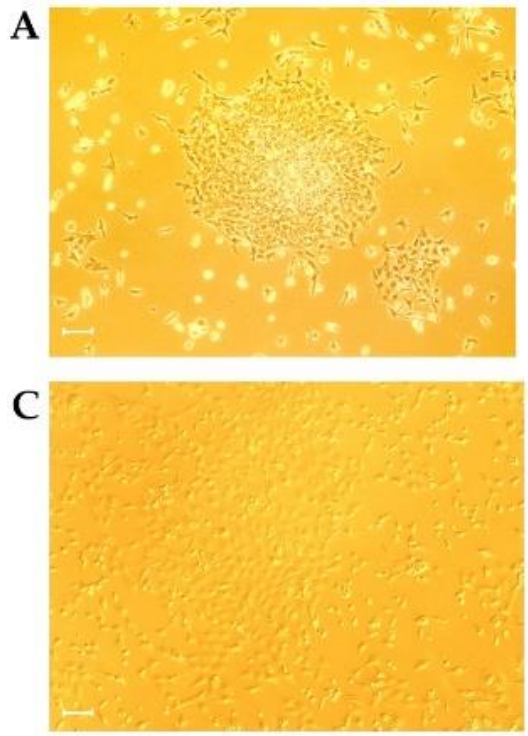

B
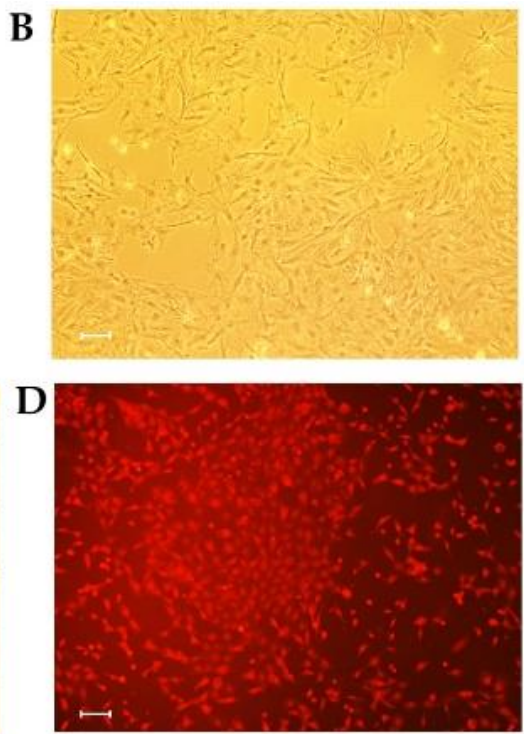

Figure 2. Isolation of granulosa cells (GCs) and transfection with Tet-on 3G Large T lentivirus. (A) The primary GCs were isolated from the ovary tissue and cultured at day 1. (B) The primary culture GCs were differentiated on the fifth day. (C,D) GCs with expression of Large T and mCherry maintained long-term proliferation as primary culture GCs. Bar at $50 \mu \mathrm{m}$.

\subsection{Large T-T2A-mCherry Expression Is Reversible in CIPGCs}

To confirm reversible Large T-T2A-mCherry expression in CIPGCs upon the removal of Dox from culture, we determined the expression of mCherry under a fluorescent microscope. It was found that the expression of mCherry began to decrease $24 \mathrm{~h}$ after Dox withdrawal (Figure 3A), and then gradually disappeared by $48 \mathrm{~h}$ (Figure 3B) and $96 \mathrm{~h}$ (Figure 3C). This was accompanied by the gradual elongation of the granulosa cells (Figure 3;-Dox). In contrast, the CIPGCs cultured in the presence of Dox continuously expressed mCherry and maintained the appearance of proliferative primary cultured GCs (Figure 3,+Dox). These results suggest that Large T expression was responsive to Dox in a time-dependent manner in CIPGCs.

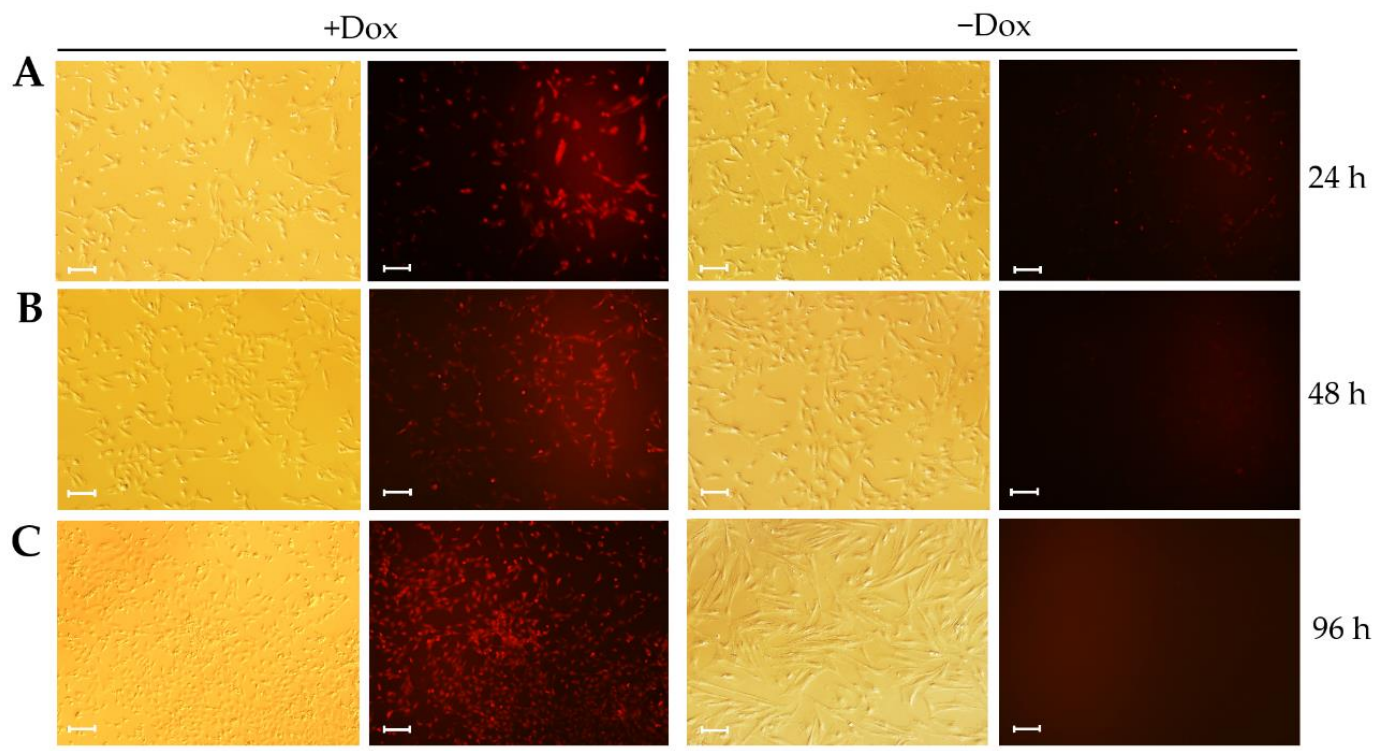

Figure 3. Dox inducible expression of Large $\mathrm{T}$ and mCherry. The mCherry expression was observed in CIPGCs with or without Dox at $24 \mathrm{~h}$ (A), $48 \mathrm{~h}$ (B), and 96 (C), respectively. CIPGCs, conditional immortal porcine GCs. The experiment was repeated three times. Bar at $50 \mu \mathrm{m}$. 


\subsection{The Proliferation of CIPGCS Is Controlled by Dox Induction}

In the presence of Dox, the CIPGC line showed proliferative morphology, in which less than $60 \%$ of the cells were at G1 phase of the cell cycle when measured via flow cytometry (Figure 4A). However, in the absence of Dox, CIPGCs demonstrated gradual elongation, and G1 phase cell percentage increased to $79 \%$ by day 6 of Dox withdrawal (Figure 4B). Consistently, cell proliferation assay revealed that, in the presence of Dox, CIPGCs grew rapidly, while they stopped proliferating in the absence of Dox (Figure 4C). These data demonstrated the distinct proliferation potential and status of CIPGCs in the absence and presence of Dox, respectively.

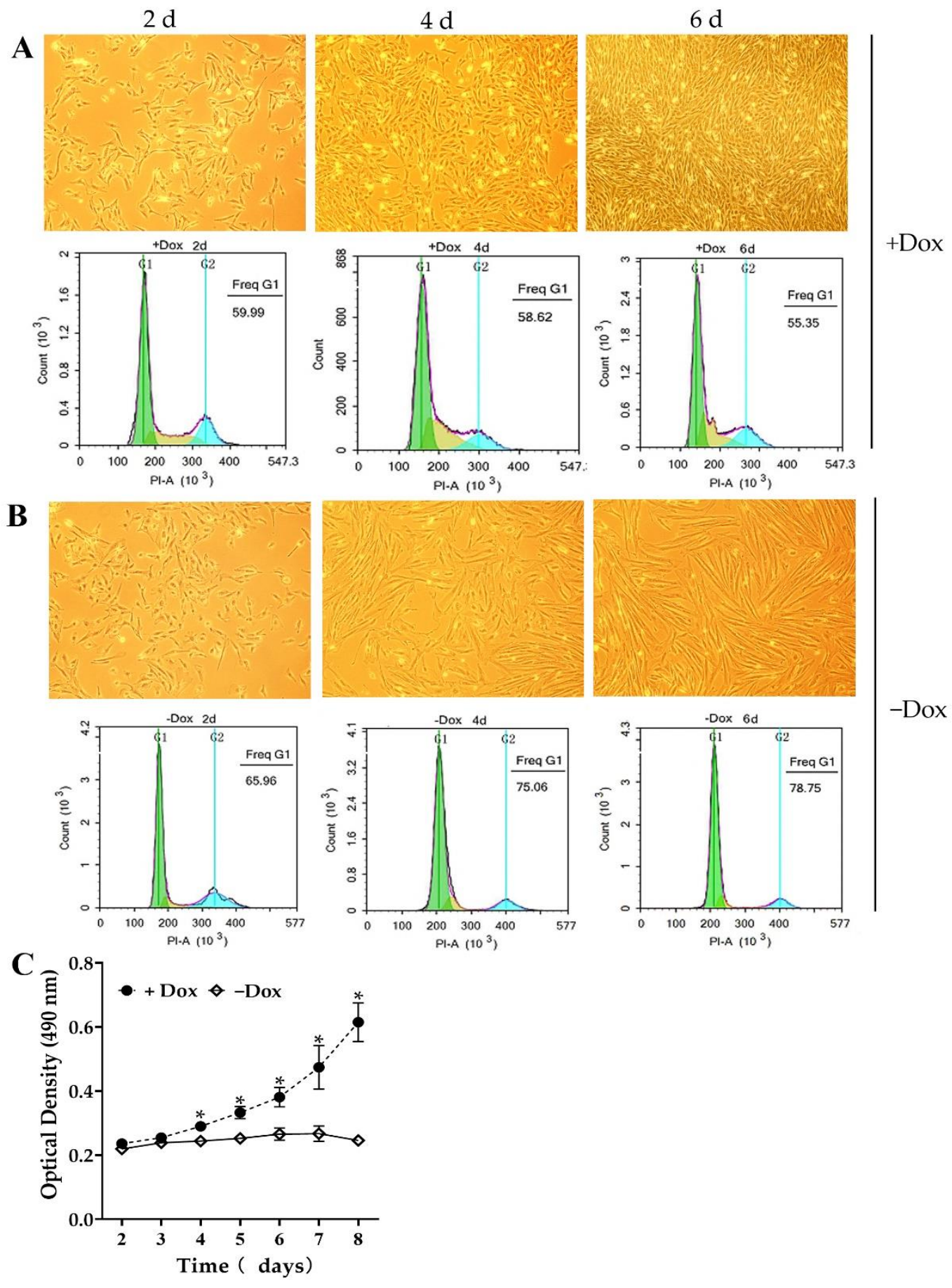

Figure 4. Proliferation of CIPGCs induced by Dox. (A) The morphology and cell cycle analysis of 
CIPGCs with Dox induction for culture. (B) The morphology and cycle analysis of CIPGCs without Dox induction for culture, cell cycle analysis showed that more cells were in S/M (Synthesis/Mitotic) phase during induction by Dox; at the withdrawal of Dox, percentage of cells in S/M phases decreased. (C) Cell proliferation curve during an eight days' culture in the presence and absence of Dox. Data are represented as mean \pm SEM of three independent experiments $(n=6) .{ }^{*}$ stands for significant difference between CIPGCs + Dox and -Dox group $(p<0.05)$. Bar at $50 \mu \mathrm{m}$.

Next, we further investigated if the CIPGCs expressed markers that are consistent with primary GCs via immunofluorescent analysis. As shown in Figure 5, follicular stimulating hormone receptor (FSHR) and enzymes involved in steroid synthesis and metabolism, such as Cytochrome progesterone 50 family 11 subfamily A member 1 (CYP11A1) and 3 $\beta$-hydroxysteroid dehydrogenase (3 $\beta$-HSD), are expressed in CIPGCs cultures in both the presence (Figure 5A) and absence of Dox (Figure 5B) after six days. However, the morphologies of these two groups of GCs were distinguishable from each other in that they were larger, and the elongated CIPGCs are apparent in the Dox (-) group.

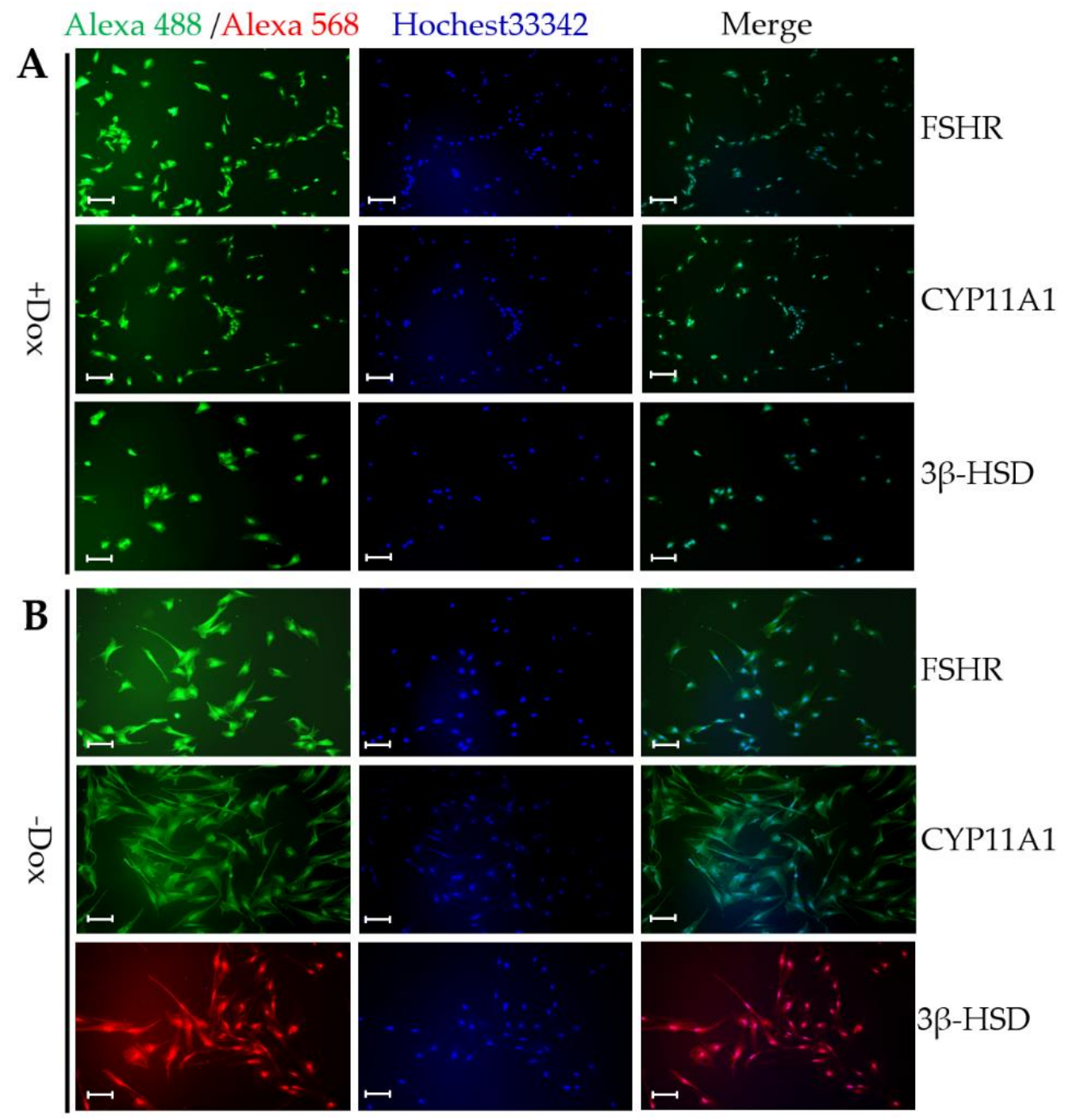

Figure 5. Expression of granulosa cell markers in the CIPGC line by immunofluorescent staining in the presence and absence of Dox. Immunofluorecent staining of FSHR, CYP11A1, and 3 $\beta$-HSD in CIPGCs with (A) and without (B) Dox induction. CYP11A1, cytochrome progesterone 50 family 11 subfamily A member $1 ; 3 \beta$-HSD, $3 \beta$-hydroxysteroid dehydrogenase; FSHR, follicular stimulating hormone receptor. The experiment was repeated twice. Bar at $50 \mu \mathrm{m}$. 
Quantitative PCR analysis further confirmed the expression of these GC markers, and revealed that the mRNA expression levels of LHR (luteinizing hormone receptor), CYP11A1 (cytochrome P450 family 11 subfamily A member 1 ), $3 \beta$-HSD (3ß-hydroxysteroid dehydrogenase), StAR (steroidogenic acute regulatory protein), and CYP19A1 (cytochrome P450 family 19 subfamily a member 1 ) were higher in the Dox (-) group compared with that of the Dox (+) group, while the mRNA expression of genes related in cell proliferation genes like LIFR (leukemia inhibitory factor receptor), PCNA (proliferating cell nuclear antigen), and CCNB1 (cyclin B1) was lower in the Dox (-) group (Figure 6A).

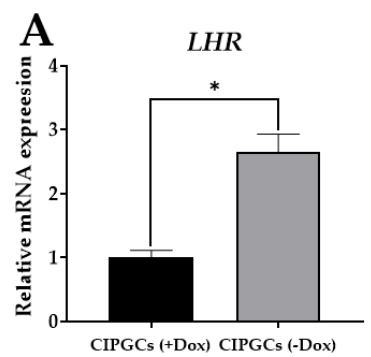

CYP19A1

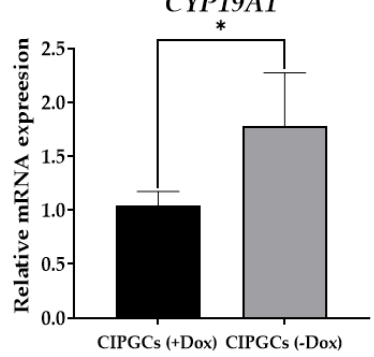

B

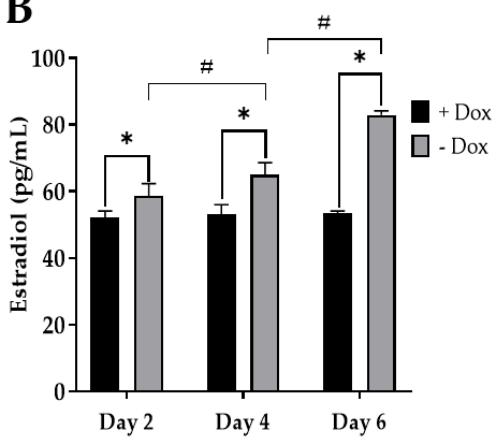

CYP11A1

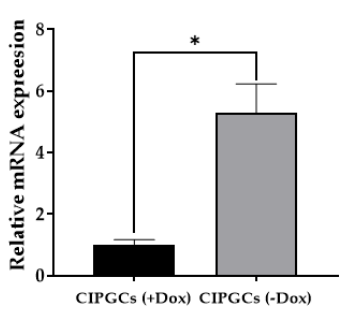

LIFR

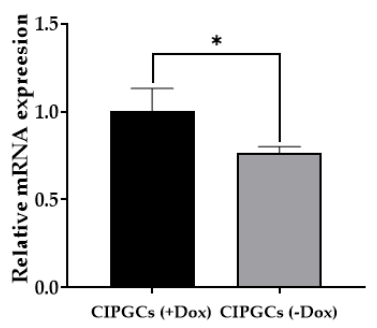

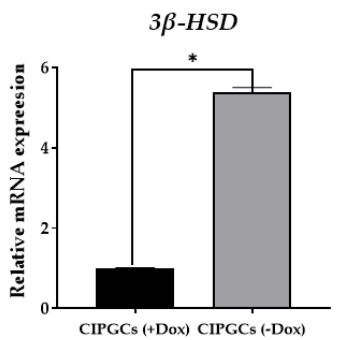

PCNA

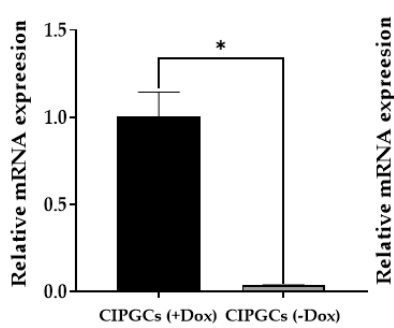

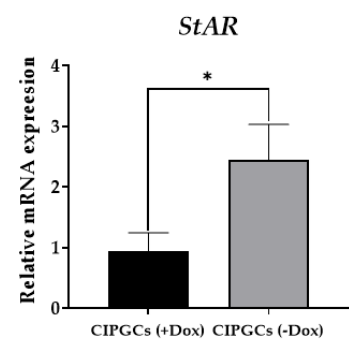

CCNB1

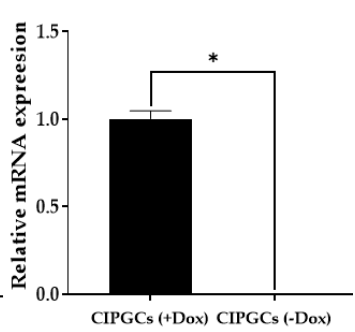

C

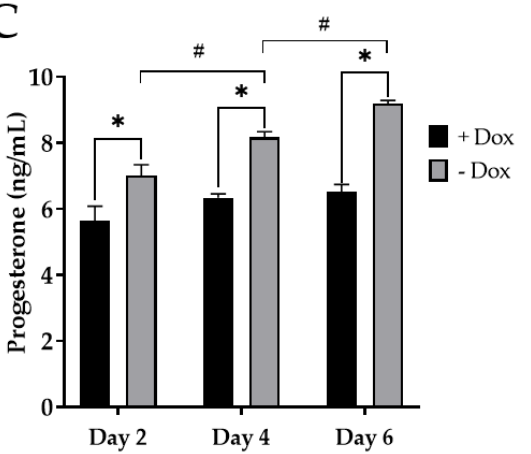

Figure 6. Expression of granulosa markers in the GC line when cultured in the presence and absence of Dox. (A) The mRNA expression of LHR, CYP11A1, 33-HSD, StAR, LIFR, PCNA, and CCNB1 by quantitative PCR after culturing for six days with or without Dox. Estradiol (B) and progesterone (C) detection by ELISA detection $(n=6)$. LHR, luteinizing hormone receptor CYP11A1, cytochrome P450 family 11 subfamily A member $1 ; 3 \beta-H S D, 3 \beta$-hydroxysteroid dehydrogenase; StAR, steroidogenic acute regulatory protein; CYP19A1, cytochrome P450 family 19 subfamily a member 1 ; LIFR, leukemia inhibitory factor receptor; $P C N A$, proliferating cell nuclear antigen; CCNB1, cyclin B1; FSH, follicular stimulating hormone; LH, luteinizing hormone. The experiment was repeated three times. * stands for significant difference between + Dox and -Dox group at specific day $(p<0.05)$. ${ }^{\#}$ stands for significant difference from three time points in the-Dox group $(p<0.05)$.

We next investigated the levels of estradiol and progesterone production by CIPGCs in the presence and absence of Dox. It was found that the levels of both estradiol and progesterone were significantly higher in the Dox (-) group compared with those with Dox addition (Figure 6B,C). Moreover, while the levels of the two hormones remain similar in the presence of Dox, both estradiol and progesterone 
showed a time-dependent increase during the six days of Dox withdrawal. This finding further confirms that GCs from the Dox (-) group are more differentiated than those from the Dox (+) group.

\subsection{The Reversible Regulation on Proliferation State of CIPGCs by Dox}

Withdrawal of Dox for 14 days resulted in the ceasing of proliferation, cell elongation, senescence, and absence of mCherry expression (Figure 7A). Interestingly, this morphology of the CIPGCs could be reversed by the addition of Dox. Two days after Dox supplementation, the CIPGCs shortened and started expressing Large $\mathrm{T}$, as reflected by mCherry fluorescence (Figure 7B). In addition, the CIPGCs became much smaller in size, and more proliferative at day 14 of Dox culture (Figure 7C). These results suggest that the induced Large T expression reversed the ageing CIPGCs to proliferative and active CIPGCs.
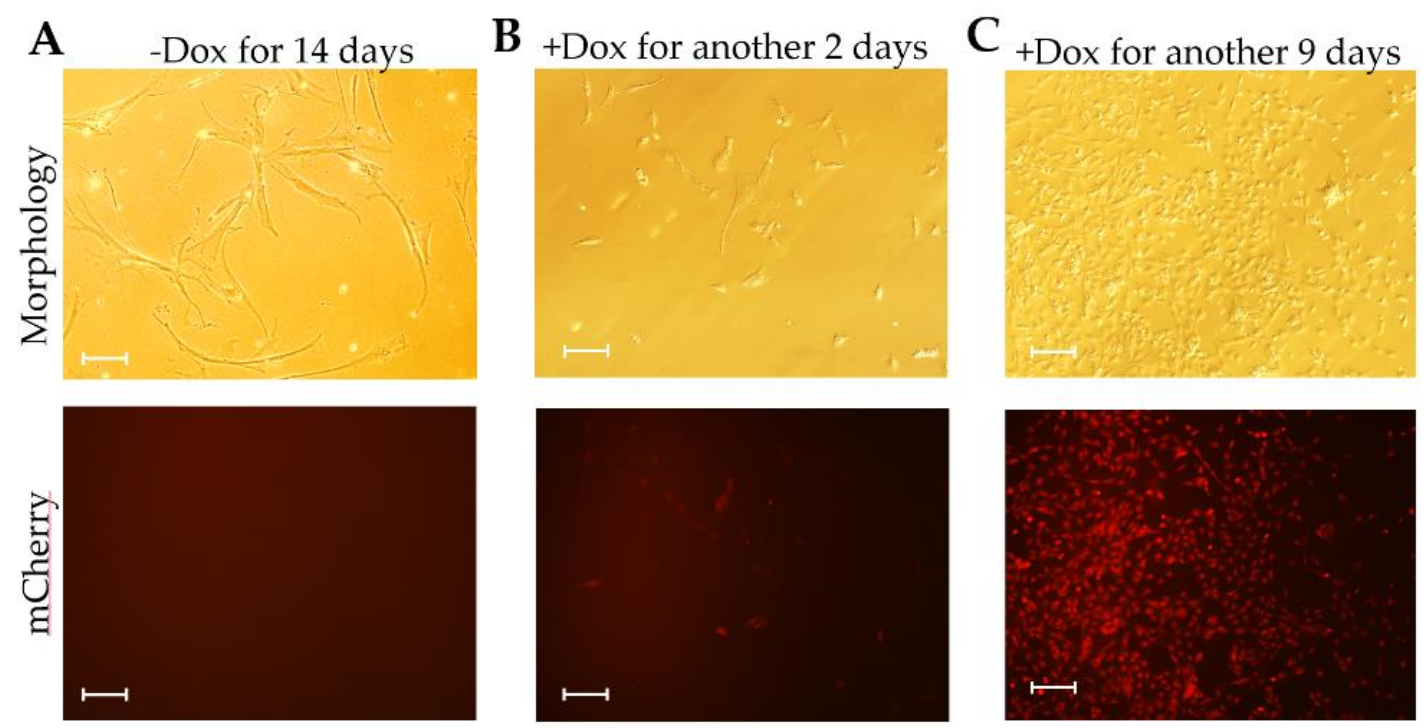

Figure 7. Morphology and phenotypic analysis of the CIPGCs after Dox withdrawal followed by Dox induction. (A) The CIPGCs became ageing after culturing without dox for 14 days and had no expression of mCherry. The ageing CIPGCs were then re-treated with dox induction for another two days (B) or nine days $(\mathbf{C})$, and the mCherry expression was recovered. Bar at $50 \mu \mathrm{m}$.

\subsection{Comparison of Steroidogenesis and Gonadotropin Response of CIPGCs and Primary GCs}

We next further examined the steroidogenesis potential and CIPGC in comparison with freshly isolated primary GC. The quantitative PCR analysis showed that the mRNA expression of hormone synthesis-related enzymes was not significant between primary GCs and GIPGCs (-Dox) + porcine follicular fluid (PFF) groups. As shown in Figure 8A,B, for the expression of key estradiol synthesis enzymes (CYP19A1 and StAR), CIPGCs without Dox addition were significantly lower than that in primary GCs (Figure 8A,B). We hypothesized that this difference may be because of the lack of exposure of the CIPGCs to the porcine follicular fluid (PFF), in which GCs are physiologically bathed. To test this hypothesis, we primed the CIPGCs with PFF. As shown in Figure 8A,B, the mRNA levels of these two key steroidogenesis enzymes are the same between CIPGCs and the primary GCs. As to be expected, priming of CIPGCs with PFF also allows the granulosa cell line to produce estradiol to the level that is the same as that of the primary GC. Moreover, PFF priming also resulted in the estradiol production of CIPGCs Dox (-) to the level that is similar to that of primary GC, although the estradiol level in the CIPGCs Dox (+) is significantly lower (Figure 8C). Interestingly, PFF priming of CIPGCs in Dox (-) group also enabled the cell line to respond to FSH and LH in estradiol production, while CIPGCs upon Dox exposure could not increase the estradiol level under FSH and LH stimulation (Figure 8D). 


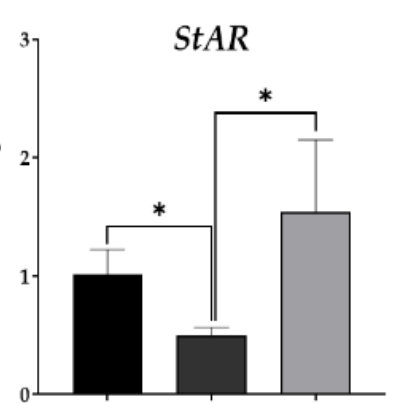

B

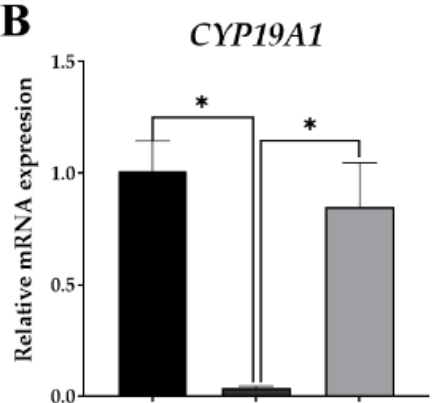

C
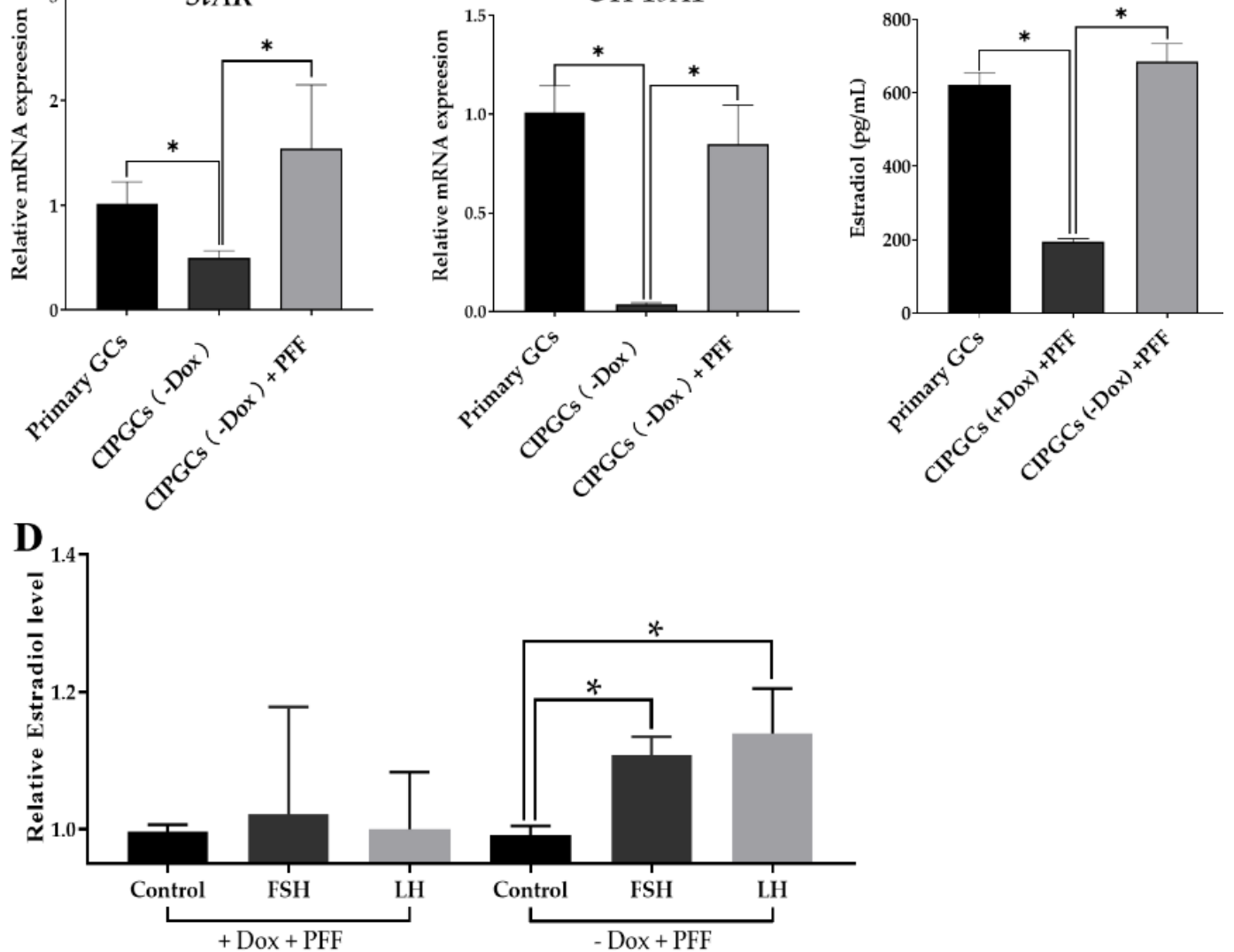

Figure 8. The function analysis of the CIPGCs. The mRNA expression of StAR (A) and CYP19A1 (B) by quantitative PCR after culturing for six days without Dox treatment in company with or without PFF when compared with primary GCs. (C) Determination of estradiol level among primary GCs, CIPGCs (+Dox), and CIPGCs (-Dox). (D) The estradiol level in the CIPGCs (-Dox) with addition of FSH and LH. PFF, porcine follicular fluid. Data are represented as mean \pm SEM of three independent experiment $(n=3)$. ${ }^{*}$ stands for significant difference between two groups $(P<0.05)$.

\section{Discussion}

The previously common method for cell immortalization is to introduce the simian virus 40 (SV40) $\mathrm{T}$ antigen into target primary cells. The large $\mathrm{T}$ antigen forms complexes with tumor suppressors, such as pRB-1 and p53, and induces DNA synthesis in both dividing and quiescent cells, leading to extension of the lifespan of the cells [26]. This approach has been used for transformation of various primary cell types [27-29]. One of the major limitations of permanent immortal cell lines is their proliferative status, which prevents the development of the full physiological phenotype [30]. This may complicate the interpretation of data obtained from these cell lines. To overcome this problem, conditional immortalization is desirable. Using this approach, inducible immortal astrocytes [31], adipocyte precursor cells [32], and hematopoietic precursor cells [33] have all been successfully established. However, an inducible immortal GC line has not been established.

In this study, we constructed a Large $\mathrm{T}$ expressing lentiviral vector driven by the tetracyclineinducible (Tet-on) system, which can switch on and off the expression of the gene, and thus regulate the proliferation of the transformed GCs in vitro. The Tet-on system has been extensively used for reversible induction of gene expression in many mammalian cells and transgenic animals [34-38]. This Tet-on 3G system is based upon the interaction between a reverse transactivator (rtTA) and the tetracycline-responsive element (TRE), which is composed of seven copies of the prokaryotic tetracycline operator site (tetO) fusing with a minimal CMV promoter. In the presence of tetracycline or 
its derivate doxycycline (Dox), the rtTA transactivator activates minimal promoters and the downstream of an array of tetO sequences, allowing the expression of the transgene [39]. The Tet-on 3G system has been claimed to possess 10-100 times higher sensitivities to Dox than the traditional Tet-on system [40]. With the inducible promoter based on the Tet-on 3G and the Tet-on 3G-response element (TRE3G) [41], our Large $\mathrm{T}$ antigen is co-expressed with mCherry (as a reporter). Our data suggest that this inducible system works efficiently in the transduced GC (CIPGCs). In the presence of Dox, CIPGC steadily expressed Large $\mathrm{T}$, having similar morphologic characteristics as primary GCs. In contrast, Large $\mathrm{T}$ expression was undetectable in the absence of Dox after $48 \mathrm{~h}$.

Our data revealed that CIPGCs exhibited the functional characteristics of primary GCs such as the expression of steroid enzymes, as well as the ability for estradiol and progesterone production. In the presence of Dox, CIPGCs were capable of continued proliferation for at least six months. Moreover, at Dox withdrawal, their cell cycle shifted toward G1 phase and gradually lost replicative ability. These CIPGCs demonstrated increased expression of LHR and enzymes such as CYP11A1, 3 $\beta-H S D$, StAR, and CYP19A1, all of which are crucial for steroid hormone production [42,43], as well as increased production of estradiol and progesterone. These data suggest that CIPGCs are capable of reversible immortalization and reulating steroidogenesis. Interestingly, upon a repeated supplementation with Dox for two days, our CIPGCs returned to the original proliferative morphology, further demonstrating the efficiency of controlled immortalization.

Although the mRNA levels of StAR and CYP19A1 were significantly lower in the CPIGCs compared with that of the freshly isolated primary GCs, the mRNA expression of these steroidogenesis genes is enhanced to the levels that are comparable to those of primary GCs, when they are cultured in the presence of PFF. This finding suggests that our CIPGCs retain the ability to function similar to primary GCs, when they are placed in an environment exposed to PFF. Our finding that estradiol production responded to FSH and LH stimulation in the presence of PFF further supports this notion. It showed that this cell line established might be inducible, stably proliferate, and reversely display the physiological function of primary cells.

In conclusion, we have successfully established an inducible porcine GC line (CIPGCs) via the Tet-on 3G system. Our established CIPGCs retain the ability of maintaining physiological functions, and may provide a unique valuable model for future research on the specific gene regulatory mechanisms of this important ovarian somatic cell.

Supplementary Materials: The following are available online at https://www.mdpi.com/2073-4409/9/1/156/s1, Table S1: Primer sequence, and accession number of target genes. Figure S1: Long-term cultivation and screening of the CIPGCs.

Author Contributions: Conceptualization, Y.B. and J.L.; data curation, Y.B., M.F., and B.P.; formal analysis, X.Z., H.C., and B.W.; Resources, S.Z.; writing—original draft, Y.B. and C.Z.; writing—review and editing, J.L., Y.B., and C.Z. Funding acquisition, Y.B. and J.L. All authors have read and agreed to the published version of the manuscript.

Funding: This work was funded by the Startup Program from Foshan University (gg040968) and the Natural Sciences and Engineering Research Council of Canada (400259).

Conflicts of Interest: The authors declare no conflict of interest to each other. The funders had no role in the design of the study; in the collection, analyses, or interpretation of data; in the writing of the manuscript; or in the decision to publish the results.

\section{References}

1. Pohler, K.G.; Geary, T.W.; Atkins, J.A.; Perry, G.A.; Jinks, E.M.; Smith, M.F. Follicular determinants of pregnancy establishment and maintenance. Cell Tissue Res. 2012, 349, 649-664. [CrossRef] [PubMed]

2. Zhen, Y.H.; Wang, L.; Riaz, H.; Wu, J.B.; Yuan, Y.F.; Han, L.; Wang, Y.L.; Zhao, Y.; Dan, Y.; Huo, L.J. Knockdown of CEBPbeta by RNAi in porcine granulosa cells resulted in $\mathrm{S}$ phase cell cycle arrest and decreased progesterone and estradiol synthesis. J. Steroid Biochem. Mol. Biol. 2014, 143, 90-98. [CrossRef] [PubMed] 
3. Breckwoldt, M.; Selvaraj, N.; Aharoni, D.; Barash, A.; Segal, I.; Insler, V.; Amsterdam, A. Expression of Ad4-BP/cytochrome P450 side chain cleavage enzyme and induction of cell death in long-term cultures of human granulosa cells. Mol. Hum. Reprod. 1996, 2, 391-400. [CrossRef] [PubMed]

4. Lin, M.T. Establishment of an immortalized porcine granulosa cell line (PGV) and the study on the potential mechanisms of PGV cell proliferation. Keio J. Med. 2005, 54, 29-38. [CrossRef]

5. Rao, I.M.; Gadson, P.J.; Anderson, E.; Hornsby, P.J.; Mahesh, V.B. Characterization of progesterone biosynthesis in a transformed granulosa cell line. Mol. Cell. Endocrinol. 1993, 94, 121-128. [CrossRef]

6. Yang, D.; Wang, L.; Lin, P.; Jiang, T.; Wang, N.; Zhao, F.; Chen, H.; Tang, K.; Zhou, D.; Wang, A.; et al. An immortalized steroidogenic goat granulosa cell line as a model system to study the effect of the endoplasmic reticulum (ER)-stress response on steroidogenesis. J. Reprod. Dev. 2017, 63, 27-36. [CrossRef]

7. Wang, H.; Wen, L.; Yuan, Q.; Sun, M.; Niu, M.; He, Z. Establishment and applications of male germ cell and sertoli cell lines. Reproduction 2016, 152, R31-40. [CrossRef]

8. Kamei, Y.; Aoyama, Y.; Fujimoto, T.; Kenmotsu, N.; Kishi, C.; Koushi, M.; Sugano, S.; Morohashi, K.; Kamiyama, R.; Asakai, R. A steroidogenic cell line with differentiation potential from mouse granulosa cells, transfected with Ad4BP and SV40 large T antigen genes. J. Endocrinol. 2005, 185, 187-195. [CrossRef]

9. Gillio-Meina, C.; Swan, C.L.; Crellin, N.K.; Stocco, D.M.; Chedrese, P.J. Generation of stable cell lines by spontaneous immortalization of primary cultures of porcine granulosa cells. Mol. Reprod. Dev. 2000, 57, 366-374. [CrossRef]

10. Havelock, J.C.; Rainey, W.E.; Carr, B.R. Ovarian granulosa cell lines. Mol. Cell. Endocrinol. 2004, 228, 67-78. [CrossRef]

11. Darimont, C.; Avanti, O.; Tromvoukis, Y.; Vautravers-Leone, P.; Kurihara, N.; Roodman, G.D.; Colgin, L.M.; Tullberg-Reinert, H.; Pfeifer, A.M.; Offord, E.A.; et al. SV40 T antigen and telomerase are required to obtain immortalized human adult bone cells without loss of the differentiated phenotype. Cell Growth. Differ. 2002, 13, 59-67. [PubMed]

12. Sadowska, A.; Nynca, A.; Korzeniewska, M.; Piasecka-Srader, J.; Jablonska, M.; Orlowska, K.; Swigonska, S.; Ciereszko, R.E. Characterization of porcine granulosa cell Line AVG-16. Folia Biol. (Praha) 2015, 61, 184-194. [PubMed]

13. Leighton, J.K.; Grimes, R.W.; Canning, S.; Hammond, J.M. Expression of the IGF system in primary and immortalized porcine ovarian granulosa cells. Mol. Cell. Endocrinol. 1993, 97, 29-35. [CrossRef]

14. Kwan, I.; Farookhi, R.; Huynh, H.T.; Murphy, B.D.; Turner, J.D.; Downey, B.R. Steroidogenic properties of a spontaneously established porcine granulosa cell line (PGC-2). Mol. Reprod. Dev. 1996, 45, $299-307$. [CrossRef]

15. Rodway, M.R.; Swan, C.L.; Gillio-Meina, C.; Crellin, N.K.; Flood, P.F.; Chedrese, P.J. Regulation of steroidogenesis in jc-410, a stable cell line of porcine granulosa origin. Mol. Cell. Endocrinol. 1999, 148, 87-94. [CrossRef]

16. Kowolik, C.M.; Liang, S.; Yu, Y.; Yee, J.K. Cre-mediated reversible immortalization of human renal proximal tubular epithelial cells. Oncogene 2004, 23, 5950-5957. [CrossRef] [PubMed]

17. Wu, H.L.; Wang, Y.; Zhang, P.; Li, S.F.; Chen, X.; Chen, Y.K.; Li, J.G.; Yang, S.M.; Su, Y.P.; Wang, J.P.; et al. Reversible immortalization of rat pancreatic beta cells with a novel immortalizing and tamoxifen-mediated self-recombination tricistronic vector. J. Biotechnol. 2011, 151, 231-241. [CrossRef]

18. He, J.; Duan, X.; Li, W.; Peng, Y.; Yu, J.; Hu, L.; Zeng, S.; Wang, Y.; Lu, G.; Lin, G.; et al. Establishment and characterization of a human embryonic stem cell line, NERCe002-A-3, with inducible 14-3-3zeta overexpression. Stem. Cell Res. 2018, 28, 11-15. [CrossRef]

19. Collet, B.; Lester, K. Establishment of an Atlantic salmon kidney cell line with an inducible gene expression system. J. Biotechnol. 2011, 154, 209-211. [CrossRef]

20. Ravassard, P.; Hazhouz, Y.; Pechberty, S.; Bricout-Neveu, E.; Armanet, M.; Czernichow, P.; Scharfmann, R. A genetically engineered human pancreatic beta cell line exhibiting glucose-inducible insulin secretion. J. Clin. Investig. 2011, 121, 3589-3597. [CrossRef]

21. Benazra, M.; Lecomte, M.J.; Colace, C.; Muller, A.; Machado, C.; Pechberty, S.; Bricout-Neveu, E.; Grenier-Godard, M.; Solimena, M.; Scharfmann, R.; et al. A human beta cell line with drug inducible excision of immortalizing transgenes. Mol. Metab. 2015, 4, 916-925. [CrossRef] [PubMed]

22. Zhang, J.; Chen, L.; Zhang, J.; Wang, Y. Drug inducible CRISPR/Cas systems. Comput. Struct. Biotechnol. J. 2019, 17, 1171-1177. [CrossRef] [PubMed] 
23. Bai, Y.; Feng, M.; Liu, S.; Wei, H.; Li, L.; Zhang, X.; Shen, C.; Zhang, S.; Ma, N. Differential gene expression in mouse spermatogonial stem cells and embryonic stem cells. Int. J. Mol. Med. 2016, 38, 423-432. [CrossRef] [PubMed]

24. Wang, X.L.; Wu, Y.; Tan, L.B.; Tian, Z.; Liu, J.H.; Zhu, D.S.; Zeng, S.M. Follicle-stimulating hormone regulates pro-apoptotic protein Bcl-2-interacting mediator of cell death-extra long (BimEL)-induced porcine granulosa cell apoptosis. J. Biol. Chem. 2012, 287, 10166-10177. [CrossRef] [PubMed]

25. Chen, F.C.; Oskay-Ozcelik, G.; Buhling, K.J.; Kopstein, U.; Mentze, M.; Lichtenegger, W.; Sehouli, J. Prognostic value of serum and ascites levels of estradiol, FSH, LH and prolactin in ovarian cancer. Anticancer Res. 2009, $29,1575-1578$.

26. Kaiser, B.; Bottner, M.; Wedel, T.; Brunner, R.M.; Goldammer, T.; Lesko, S.; Gabel, G.; Gleich, A.; Pfannkuche, H. Establishment and characterization of an SV40 Large T antigen-transduced porcine colonic epithelial cell line. Cells Tissues Organs 2017, 203, 267-286. [CrossRef]

27. Chen, Y.; Hu, S.; Wang, M.; Zhao, B.; Yang, N.; Li, J.; Chen, Q.; Liu, M.; Zhou, J.; Bao, G.; et al. Characterization and Establishment of an immortalized rabbit melanocyte cell Line using the SV40 Large T antigen. Int. J. Mol. Sci. 2019, 20, 4874. [CrossRef]

28. Hou, J.; Niu, M.; Liu, L.; Zhu, Z.; Wang, X.; Sun, M.; Yuan, Q.; Yang, S.; Zeng, W.; Liu, Y.; et al. Establishment and Characterization of human germline stem cell line with unlimited proliferation potentials and no tumor formation. Sci. Rep. 2015, 5, 16922. [CrossRef]

29. Blum, W.; Pecze, L.; Felley-Bosco, E.; Worthmuller-Rodriguez, J.; Wu, L.; Vrugt, B.; de Perrot, M.; Schwaller, B. Establishment of immortalized murine mesothelial cells and a novel mesothelioma cell line. In Vitr. Cell. Dev. Biol. Anim. 2015, 51, 714-721. [CrossRef]

30. Daniele, N.; Halse, R.; Grinyo, E.; Yeaman, S.J.; Shepherd, P.R. Conditionally immortalized cell lines as model systems for high-throughput biology in drug discovery. Biochem. Soc. Trans. 2002, 30, 800-802. [CrossRef]

31. Liu, Y.; Patel, G.C.; Mao, W.; Clark, A.F. Establishment of a conditionally immortalized mouse optic nerve astrocyte line. Exp. Eye Res. 2018, 176, 188-195. [CrossRef] [PubMed]

32. Church, C.; Brown, M.; Rodeheffer, M.S. Conditional immortalization of primary adipocyte precursor cells. Adipocyte 2015, 4, 203-211. [CrossRef] [PubMed]

33. Leithner, A.; Renkawitz, J.; De Vries, I.; Hauschild, R.; Hacker, H.; Sixt, M. Fast and efficient genetic engineering of hematopoietic precursor cells for the study of dendritic cell migration. Eur. J. Immunol. 2018, 48, 1074-1077. [CrossRef] [PubMed]

34. Fan, X.; Petitt, M.; Gamboa, M.; Huang, M.; Dhal, S.; Druzin, M.L.; Wu, J.C.; Chen-Tsai, Y.; Nayak, N.R. Transient, inducible, placenta-specific gene expression in mice. Endocrinology 2012, 153, 5637-5644. [CrossRef] [PubMed]

35. Zhu, Z.; Zheng, T.; Lee, C.G.; Homer, R.J.; Elias, J.A. Tetracycline-controlled transcriptional regulation systems: Advances and application in transgenic animal modeling. Semin. Cell Dev. Biol. 2002, 13, 121-128. [CrossRef]

36. Xu, K.; Deng, X.Y.; Yue, Y.; Guo, Z.M.; Huang, B.; Hong, X.; Xiao, D.; Chen, X.G. Generation of the regulatory protein rtTA transgenic mice. World J. Gastroenterol. 2005, 11, 2885-2891. [CrossRef]

37. Iwata, H. Age-associated changes in granulosa cells and follicular fluid in cows. J. Reprod. Dev. 2017, 63, 339-345. [CrossRef]

38. Das, A.T.; Zhou, X.; Metz, S.W.; Vink, M.A.; Berkhout, B. Selecting the optimal Tet-On system for doxycycline-inducible gene expression in transiently transfected and stably transduced mammalian cells. Biotechnol. J. 2016, 11, 71-79. [CrossRef]

39. Xu, E.Y.; Lee, D.F.; Klebes, A.; Turek, P.J.; Kornberg, T.B.; Reijo, P.R. Human BOULE gene rescues meiotic defects in infertile flies. Hum. Mol. Genet. 2003, 12, 169-175. [CrossRef]

40. Xu, E.Y.; Moore, F.L.; Pera, R.A. A gene family required for human germ cell development evolved from an ancient meiotic gene conserved in metazoans. Proc. Natl. Acad. Sci. USA 2001, 98, 7414-7419. [CrossRef]

41. Zhou, X.; Vink, M.; Klaver, B.; Berkhout, B.; Das, A.T. Optimization of the Tet-On system for regulated gene expression through viral evolution. Gene. Ther. 2006, 13, 1382-1390. [CrossRef] [PubMed] 
42. Rodway, M.R.; Swan, C.L.; Crellin, N.K.; Gillio-Meina, C.; Chedrese, P.J. Steroid regulation of progesterone synthesis in a stable porcine granulosa cell line: A role for progestins. J. Steroid. Biochem. Mol. Biol. 1999, 68, 173-180. [CrossRef]

43. Chen, Y.L.; Yu, C.P.; Lee, T.H.; Goh, K.S.; Chu, K.H.; Wang, P.H.; Ismail, W.; Shih, C.J.; Chiang, Y.R. Biochemical mechanisms and catabolic enzymes involved in bacterial estrogen degradation pathways. Cell Chem. Biol. 2017, 24, 712-724. [CrossRef] [PubMed]

(C) 2020 by the authors. Licensee MDPI, Basel, Switzerland. This article is an open access article distributed under the terms and conditions of the Creative Commons Attribution (CC BY) license (http://creativecommons.org/licenses/by/4.0/). 